\title{
Funkcje narzędzi wykorzystywanych w polityce przestrzennej
}

\section{Streszczenie}

Celem artykułu jest określenie funkcji narzędzi polityki przestrzennej oraz płaszczyzn, na których mogą być one stosowane. Analizą objęto w szczególności kluczowe narzędzia polityki przestrzennej - miejscowe plany zagospodarowania przestrzennego. Jako istotną ich funkcję określono ochronę ładu przestrzennego. Niezależnie od powyższego, narzędziom polityki przestrzennej można również przyporządkować funkcje ważne z innych perspektyw: ochrony środowiska, polityki socjalnej lub ochrony dziedzictwa kulturowego.

Słowa kluczowe: ład przestrzenny, polityka przestrzenna, miejscowe plany zagospodarowania przestrzennego, środowisko

DOI: $10.33119 / \mathrm{KSzPP} .2019 .3 .4$

\section{Functions of spatial policy instruments}

\begin{abstract}
The aim of the article is to determine the functions of spatial policy instruments and to determine the aspects in which a spatial policy instrument could be used. Analyses pertain to especially local plans of spatial management. The most important function is the protection of spatial order. Besides, spatial policy instruments could have other functions, connected with the environment, social policy or antique protection.
\end{abstract}

Keywords: spatial order, spatial policy, local plans of spatial management, functions, environment

1 Pracownia Prawa i Gospodarki Nieruchomościami, Katedra Nieruchomości, Wydział Ekonomiczny, Zachodniopomorski Uniwersytet Technologiczny w Szczecinie 
Stosowanie narzędzi polityki przestrzennej można uznać za jedno z najbardziej problematycznych zagadnień i wyzwań w sferze polityki publicznej. Dylematy dotyczą przede wszystkim tego, jak chronić ład przestrzenny oraz dotyczą sposobu kształtowania reguł zagospodarowania określonego terenu. Stosowanie narzędzi polityki przestrzennej musi zostać wkomponowane w swoistą grę o przestrzeń. Jej interesariusze próbują nierzadko narzucić swój subiektywny punkt widzenia. W tym ujęciu kluczowe wydaje się przede wszystkim precyzyjne określenie funkcji wspomnianych narzędzi.

Celem artykułu jest określenie funkcji narzędzi polityki przestrzennej oraz płaszczyzn, na których te narzędzia mogą być stosowane z perspektywy innych zadań władzy publicznej. Jak wskazuje m.in. Hausner (2007: 54), uwzględnienie i analiza dostępnych uwarunkowań instytucjonalnych oraz narzędzi stanowią jeden z podstawowych wymogów realizacji polityki publicznej. Na podstawie analiz przeprowadzonych przez Szarfenberga (2016: 66) uznać należy, że realizacja przedstawionego powyżej celu artykułu pozwoli doprecyzować to, jaki jest wpływ władzy publicznej - poprzez ukazanie charakterystyki narzędzi polityki przestrzennej - na problemy występujące w systemie gospodarki przestrzennej (chaos przestrzenny). Pozwoli również zdiagnozować problemy i możliwe reakcje (związane z zastosowaniem narzędzi polityki przestrzennej) z innych perspektyw: ochrony środowiska, przyrody, dziedzictwa kulturowego itd ${ }^{2}$. Zastrzec trzeba jednocześnie, podzielając opinię A. Zybały (2015, s. 33) o coraz mniejszej efektywności narzędzi polityki przestrzennej np. w polityce miejskiej, że realizacja celu artykułu pozwoli wykroczyć poza perspektywę wyłącznie prawną. W tym kontekście za bardzo ważne uznać należy przypisanie narzędziom polityki przestrzennej znacznie szerszych funkcji - właśnie nie tyle z perspektywy zmian prawnych, ile raczej ich koncepcyjnego ujęcia w polityce publicznej. O ile bowiem podejmowano w literaturze próby określania pojedynczych funkcji narzędzi polityki przestrzennej, to jednak zdaniem autora doprecyzowania wymaga (z perspektywy nauk o polityce publicznej) kompleksowe wyodrębnienie, skategoryzowanie tychże funkcji oraz przyporządkowanie ich do poszczególnych (również osobno skategoryzowanych) narzędzi polityki przestrzennej.

2 Występuje $\mathrm{w}$ tym zakresie sfera niedookreślona. Teoretycznie narzędzia polityki przestrzennej powinny co do zasady zapewniać realizację wskazanych celów. W praktycznym wymiarze, bardzo często niniejsze kwestie są od siebie rozdzielone. Np. z perspektywy podmiotów/organów dbających o ochronę walorów kulturowych terenów nie jest kluczowe zrealizowanie wszystkich funkcji narzędzi polityki przestrzennej, ale wyłącznie tych, które są ważne z ich perspektywy. 


\section{Klasyfikacja narzędzi polityki przestrzennej}

W literaturze przedmiotu nie budzi wątpliwości kwestia, że przestrzeń wymaga racjonalnego wykorzystania i kształtowania przez władze publiczne (Kotulski, 2012: 38; Knieling, Othengrafen 2015: 2133-2147), których głównym celem w gospodarce przestrzennej powinna być ochrona ładu przestrzennego. K. Kuciński wskazuje, że zadania władz publicznych można sprowadzić m.in. do zachowania logiki przestrzennej, czytelności przestrzennej, jak również walorów środowiska przyrodniczego (Kuciński, 2009: 55). Można podkreślić, że zagadnienia związane z ochroną ładu przestrzennego znajdują również odzwierciedlenie w dokumentach dotyczących europejskiej polityki spójności³

Brak ochrony ładu przestrzennego przynosi wymierne koszty i straty (Kowalewski, Markowski, Śleszyński, 2018: 7). Niniejsza perspektywa jest również podzielana w ujęciu prawniczym. H. Izdebski słusznie zaznacza, że zapewnianie ładu przestrzennego stanowi wyraz działania w imię interesu publicznego, a w konsekwencji realizacji wartości zawartych w Konstytucji RP (Izdebski, 2013: 27). Według różnych podejść, ochrona ładu przestrzennego, a właściwie ochrona wartości związanych $\mathrm{z}$ ładem przestrzennym ${ }^{4}$, jest więc uzasadniona. Natomiast sposoby tej ochrony mogą być zróżnicowane, nie tylko za pomocą instrumentów prawnych, ale również stawiania celów, np. społecznych czy powiązanych z ochroną środowiska. Z kolei istotna jest tu także rola narzędzi polityki przestrzennej, które powinny przyczynić się znacząco - choćby w podstawowym zakresie - do realizacji celów związanych $\mathrm{z}$ ładem przestrzennym.

Pod pojęciem narzędzi polityki przestrzennej rozumiem poniżej wszelkie akty, uchwały i rozstrzygnięcia władzy publicznej, które wywierają pośredni lub bezpośredni wpływ na zagospodarowanie danego terenu (docelowo to zagospodarowanie powinno być w zgodzie $\mathrm{z}$ ładem przestrzennym). W powyższej definicji - z kilku

3 Trzeba jednak zastrzec, że polityka przestrzenna jako taka nie stanowi kompetencji Unii Europejskiej. Analizując z perspektywy zmian regulacji prawnych, należy więc wskazać, że wstąpienie Polski do Unii Europejskiej nie przyczyniło się w żadnym stopniu do stworzenia narzędzi lepiej chroniących ład przestrzenny. Można co najwyżej dyskutować, czy część dokumentów rozwojowych (różnych szczebli) nie obejmuje w szerszym zakresie niniejszego aspektu. Stwierdzanie jednak zbyt daleko idących zależności w tej materii byłoby błędne. Ewentualnych zależności można co najwyżej poszukiwać przy określaniu powodów zmian regulacji dotyczących rewitalizacji.

4 W literaturze wskazuje się, że pojęcie ładu przestrzennego w ujęciu prawnym jest nazbyt ogólne. Nie do końca można się zgodzić z takim stanowiskiem. Ład przestrzenny z natury rzeczy musi być ujmowany szerzej (tym bardziej, że w takim ujęciu można go powiązać z interesem publicznym i literaturą obejmującą inne niż prawnicze dyscypliny). Problemem jest przede wszystkim zapewnienie realnej ochrony wartości z nim związanych, co jest kwestią odpowiednich narzędzi polityki przestrzennej. 
powodów - zdecydowano, że kluczowym punktem odniesienia będzie zagadnienie sposobu zagospodarowania terenu.

Przede wszystkim można przyjąć, że określenie sposobu zagospodarowania terenu stanowi jeden z głównych elementów polityki przestrzennej (przy zastrzeżeniu, że niemożliwe jest określenie zasad zagospodarowania danego terenu na zawsze; będą one podlegały sukcesywnym zmianom). To właśnie określenie sposobu zagospodarowania terenu (w sposób wiążący, powodujące realne, oczekiwane przez podmioty polityki przestrzennej konsekwencje prawne) będzie realnym i wymiernym punktem odniesienia, również przy ocenie tej polityki np. w sferze lokalnej.

Nie każde narzędzie polityki przestrzennej będzie precyzyjnie określać niniejsze zagospodarowanie (nawet, jeżeli wniosek taki wynikałby z konkretnych przepisów ustawowych), jednak każde będzie w jakimś stopniu określać do tego podstawy, wywierając na to choćby fragmentaryczny, ale znaczący wpływ.

Punktem odniesienia nie może być natomiast zawsze określenie przeznaczenia terenu - zarówno w obecnym systemie, jak również w kluczowych koncepcjach teoretycznych funkcja ta przypisywana jest jedynie wybranym narzędziom (np. decyzja o warunkach zabudowy ani w sposób bezpośredni, ani pośredni nie określa przeznaczenia terenu).

Należy również podkreślić, że efektem finalnym zastosowania narzędzi polityki przestrzennej powinno być takie zagospodarowanie terenu, które w możliwie największym stopniu chroni jego walory związane z ładem przestrzennym. Dyskusyjna będzie kwestia, czy stosowanie wzmiankowanych narzędzi ukierunkowane na odmienne cele, może być określane jako ich „umiejętne” stosowanie. Na przykład można sporządzić dla danego terenu miejscowy plan zagospodarowania przestrzennego, pozwalający szybko zrealizować dużą inwestycję, bez dostatecznego uwzględniania walorów kompozycyjno-estetycznych czy środowiskowych danego terenu. W wielu gminach taka możliwość jest zresztą w szerokim stopniu wykorzystywana. Znaczącej części planów miejscowych nie da się skutecznie podważyć przed sądami administracyjnymi. Takiej praktyki nie można jednak oceniać jako „umiejętne” stosowanie narzędzi polityki przestrzennej, ale raczej jako nadużywanie - w kontekście celów polityki przestrzennej - ram prawnych.

$\mathrm{Z}$ drugiej jednak strony, podjęcie $\mathrm{w}$ definicji narzędzi polityki przestrzennej tylko np. skutków w postaci ochrony walorów związanych z ładem przestrzennym doprowadziłoby do zbyt szerokiego ich wyodrębnienia (dlatego też ochrona wartości związanych z ładem przestrzennym powinna być podkreślona jako efekt finalny, ale konieczne jest odwołanie się, jak to zaproponowano powyżej, do zagospodarowania terenu). 


\section{Typologia narzędzi polityki przestrzennej}

Narzędzia polityki przestrzennej można klasyfikować na różne sposoby. Jako podstawową klasyfikację należy zaproponować:

- bezpośrednie narzędzia polityki przestrzennej (Nowak, 2012: 53),

- pośrednie narzędzia polityki przestrzennej.

Do pierwszej grupy zaliczyć należy wszystkie narzędzia ujęte w ustawie o planowaniu i zagospodarowaniu przestrzennym (choć w szerszym kontekście można stwierdzić, że ujęcie narzędzi w jednym lub kilku aktach prawnych w żadnym razie nie musi być zawsze elementem przesądzającym).

Do głównych, realnie stosowanych bezpośrednich narzędzi polityki przestrzennej należy zaliczyć:

- plan zagospodarowania przestrzennego województwa,

- studium uwarunkowań i kierunków zagospodarowania przestrzennego,

- miejscowe plany zagospodarowania przestrzennego,

- decyzje o warunkach zabudowy i zagospodarowania terenu (z pewnymi zastrzeżeniami).

Z kolei do głównych sektorowych bezpośrednich narzędzi polityki przestrzennej należy zaliczyć:

- tzw. uchwałę reklamową,

- miejscowe plany rewitalizacji,

- uchwały o ustaleniu lokalizacji inwestycji mieszkaniowej (spoza ustawy o planowaniu i zagospodarowaniu przestrzennym),

- lokalne standardy urbanistyczne.

Sektorowe bezpośrednie narzędzia polityki przestrzennej ukierunkowane są bezpośrednio na wywołanie skutków w ramach systemu gospodarki przestrzennej (i to jest ich główne zadanie). Nie obejmują swoim zasięgiem kompleksowo wszystkich problemów przestrzennych występujących na danym terenie, ale odnoszą się wyłącznie do wybranych kwestii.

Już w tym miejscu należy zastrzec, że plan zagospodarowania przestrzennego województwa w ograniczonym stopniu determinuje szczegółowe zagospodarowanie danego terenu, niemniej, jak wskazano wcześniej, stanowić będzie dla niego - w szerokim stopniu - realną podstawę (Gorzym-Wilkowski, 2013: 212).

Spośród narzędzi bezpośrednich decyzja o warunkach zabudowy i zagospodarowania terenu stwarza najmniejsze ryzyko dla ochrony ładu przestrzennego (nie wliczając pojmowanej sektorowo uchwały o ustaleniu lokalizacji inwestycji mieszkaniowej). 
Z kolei pośrednie narzędzia polityki przestrzennej również wywierają znaczący wpływ na zagospodarowanie określonego terenu, jednak główny cel ich ustanowienia był inny. Ich katalog będzie znacznie szerszy. Wśród najważniejszych wyróżnić należy:

- strategie rozwoju lokalnego,

- rozstrzygnięcia w przedmiocie wywłaszczeń nieruchomości,

- uchwały dotyczące scaleń i podziałów nieruchomości,

- rozstrzygnięcia dotyczące ewidencyjnych podziałów nieruchomości,

- ujęte w różny sposób zasady obrotu nieruchomościami publicznymi oraz gospodarowania mieszkaniowym zasobem nieruchomości.

Już z perspektywy niniejszej klasyfikacji można uznać, że także bezpośrednie narzędzia polityki przestrzennej powinny być - na podobnej zasadzie - wykorzystywane i analizowane również z innych perspektyw, na przykład społecznej, środowiskowej czy kulturowej. Przy czym już w tym miejscu należy zwrócić uwagę na to, że inne cele nie mogą zastępować ani wypierać głównego, związanego z ochroną ładu przestrzennego. Nie mogą jednocześnie zaburzać i tak nadwątlonej klarowności systemu gospodarki przestrzennej.

\section{Podstawowa klasyfikacja funkcji narzędzi polityki przestrzennej}

Narzędzia polityki przestrzennej mają przypisywane bardziej szczegółowe funkcje, przede wszystkim w literaturze typowo prawniczej. K. Małysa-Sulińska (2008: 188-189, 235-236) dla studium uwarunkowań wyróżniła następujące funkcje:

- kształtowanie i wykładnię polityki rozwoju przestrzennego gminy,

- koordynację ustaleń planów miejscowych oraz promocję (tak też Niewiadomski, 2016: 68).

Z kolei do funkcji planu należy regulowanie zasad kształtowania ładu przestrzennego na danym obszarze. P. Kwaśniak wyodrębnia następujące funkcje planów miejscowych:

- koordynacja działań podejmowanych na podstawie planów,

- motywacja użytkowników przestrzeni,

- funkcja informacyjno-planistyczna (Kwaśniak, 2008: 101).

Leoński, Szewczyk i Kruś (2012: 90-94) przypisują studium uwarunkowań przede wszystkim rolę , artykułowania polityki przestrzennej gminy”, a planowi miejscowemu ustalanie przeznaczenia terenów i warunków zabudowy.

Z kolei I. Zachariasz (2015: 29) jako funkcje planu miejscowego określa - za brzmieniem ustawy o planowaniu i zagospodarowaniu przestrzennym - ustalenie 
przeznaczenia terenu, rozmieszczenie inwestycji celu publicznego oraz określenie sposobów zagospodarowania i warunków zabudowy terenu. Przedmiotowe ujęcia są do siebie zbliżone. Trudno zarazem zakwestionować ich poprawność. Niemniej, z powyższego przekrojowego ujęcia wynika jeden problem - dosyć chaotyczne operowanie stopniem szczegółowości przypisanych do poszczególnych narzędzi funkcji.

Kluczowe funkcje narzędzi polityki przestrzennej można rozpatrywać z dwóch perspektyw: długookresowej oraz krótkookresowej (podkreślając wagę planowania strategicznego w procesie planowania i zagospodarowania przestrzennego, Herspergera et al., 2018: 32-40).

W przypadku pierwszej perspektywy naczelną funkcją narzędzi jest ochrona ładu przestrzennego, co można utożsamiać także z interesem publicznym. W literaturze przedmiotu zaproponowano liczne wskaźniki oceny zakresu ochrony wartości związanych z ładem przestrzennym (np. Śleszyński, 2013: 183-224). Realizacja wskazanej funkcji napotyka poważne bariery.

W procesie programowania sposobu wykorzystania narzędzi polityki przestrzennej, jak również późniejszego jego weryfikowania pojawiają się następujące problemy:

- ograniczona determinacja przedstawicieli władz publicznych związana z realizacją tej funkcji,

- niezrozumienie, jak też zbyt szerokie (ogólne) zrozumienie pojęcia ładu przestrzennego (co można również łączyć z problematyką kapitału społecznego w poszczególnych społecznościach w tym zakresie),

- jawne lub domniemane przeciwstawienie ochronie ładu przestrzennego praw właścicieli nieruchomości,

- przepisy prawne, które nie gwarantują (nie wliczając w to ogólnych deklaracji) ochrony walorów związanych z ładem przestrzennym na etapie realizacyjnym polityki przestrzennej.

W powyższym kontekście zasadne wydaje się nawiązanie do problematyki niesprawności władz publicznych w systemie gospodarki przestrzennej. Z przeprowadzonych badań (Nowak, 2017: 221) wynika, że władze znaczącej części polskich gmin nie uznają nawet formalnie zasady ładu przestrzennego jako naczelnej zasady programowania polityki przestrzennej.

Ma to liczne konsekwencje, skutkuje m.in. stosowaniem poszczególnych narzędzi w celach rażąco odmiennych, np. masowe odrolnienia terenów przy biernej polityce przestrzennej w pozostałym zakresie. Widoczny jest również brak uwzględniania kwestii związanych z ładem przestrzennym przy stosowaniu poszczególnych przepisów, np. wydawanie pozytywnych decyzji o warunkach zabudowy w sytuacji bez podstaw lub pomijanie obligatoryjnego elementu uchwalanego planu miejscowego: właśnie zasad ochrony i kształtowania ładu przestrzennego. 
Przechodzę teraz do drugiej perspektywy, czyli krótkookresowej perspektywy w stosowaniu narzędzi polityki przestrzennej. Można tu wymienić następujące funkcje:

- określenia regionalnych i ponadregionalnych ram realizacyjnych,

- określenia koncepcji polityki przestrzennej gminy,

- określenia przeznaczenia i szczegółowych zasad zagospodarowania danych terenów.

Funkcje te w obecnym systemie mogą być przypisane do konkretnych narzędzi. Dobór narzędzi może być jednak modyfikowany w wyniku dyskusji nad zmianami systemu. Warto to podkreślić zwłaszcza w kontekście występującej w literaturze (często w pełni słusznej) krytyki wybranych narzędzi polityki przestrzennej w obecnej formule. Dlatego też trzeba przyjąć, że w przypadku ewentualnej nowelizacji ustawy o planowaniu i zagospodarowaniu przestrzennym kluczowe jest przede wszystkim zachowanie dbałości o realizację konkretnych funkcji. Narzędzia w tym celu mogą być zmieniane, a nawet usuwane.

W tabeli 1 zaproponowano klasyfikację funkcji bezpośrednich narzędzi polityki przestrzennej. Nie uwzględniono tu jednak decyzji o warunkach zabudowy i zagospodarowania terenu. Trudno bowiem przyporządkować niniejszemu narzędziu - w sposób niebudzący wątpliwości z perspektywy systemowej - konkretnych funkcji.

Tabela 1. Podstawowe funkcje bezpośrednich narzędzi polityki przestrzennej

\begin{tabular}{|c|c|c|}
\hline $\begin{array}{l}\text { Funkcje bezpośrednich narzędzi polityki przestrzennej } \\
\text { z uwzględnieniem horyzontu czasowego oraz charakteru }\end{array}$ & $\rightarrow$ & $\begin{array}{c}\text { Funkcje bezpośrednich narzędzi polityki } \\
\text { przestrzennej z perspektywy zadań podmiotów } \\
\text { polityki przestrzennej }\end{array}$ \\
\hline Długookresowa funkcja narzędzi polityki przestrzennej (A) & & $\begin{array}{l}\text { - ochrona wartości związanych z ładem } \\
\text { przestrzennym }\end{array}$ \\
\hline Krótkookresowe funkcje narzędzi polityki przestrzennej (B) & & $\begin{array}{l}\text { - określenie regionalnych i ponadregionalnych ram } \\
\text { realizacyjnych } \\
\text { - określenie koncepcji polityki przestrzennej gminy } \\
\text { - określenie przeznaczenia i zasad } \\
\text { zagospodarowania danych terenów }\end{array}$ \\
\hline $\begin{array}{l}\text { Krótkookresowe funkcje narzędzi polityki przestrzennej, } \\
\text { które mają charakter strategiczno-programowy, } \\
\text { realizowane przez następujące narzędzia: } \\
\text { plan zagospodarowania przestrzennego województwa, } \\
\text { studium uwarunkowań i kierunków zagospodarowania } \\
\text { przestrzennego (C1) }\end{array}$ & & $\begin{array}{l}\text { - określenie koncepcji (lub podstaw dla } \\
\text { stworzenia koncepcji) polityki przestrzennej } \\
\text { - określenie ograniczeń dla polityki przestrzennej } \\
\text { na etapie realizacyjnym } \\
\text { - } \text { podwyższanie kapitału społecznego }\end{array}$ \\
\hline $\begin{array}{l}\text { Krótkookresowe funkcje narzędzi polityki przestrzennej } \\
\text { o charakterze realizacyjnym: realizowane przez miejscowy } \\
\text { plan zagospodarowania przestrzennego - (C2) }\end{array}$ & & $\begin{array}{l}\text { - określenie przeznaczenia terenu } \\
\text { - określenie szczegółowych zasad zabudowy } \\
\text { i zagospodarowania terenu }\end{array}$ \\
\hline
\end{tabular}

Źródło: opracowanie własne.

Pozostaje mi zatem ograniczyć się do konstatacji, że również to narzędzie powinno chronić ład przestrzenny. Działoby się tak, gdyby władze lokalne szczegółowo określały zasady zabudowy i zagospodarowania terenu, co obecnie robią w bardzo 
ograniczonym stopniu. Co do zasady do przypisanych funkcji można dostosować również narzędzia sektorowe.

$\mathrm{W}$ tabeli 1 zrezygnowano $\mathrm{z}$ wyodrębniania funkcji informacyjnej narzędzi, a tym bardziej „promocyjnej”. Elementy z tym związane zostały ujęte przy narzędziach o charakterze strategiczno-programowym $\mathrm{w}$ ramach funkcji polegającej na "podwyższaniu kapitału społecznego".

W analizowanym kontekście należy zwrócić uwagę na jeszcze jeden problem. Otóż wszystkie wskazane powyżej funkcje poszczególnych narzędzi polityki przestrzennej muszą być realizowane (odpowiednio stosowane), jeśli system gospodarki przestrzennej ma działać prawidłowo.

Jeśli w danej gminie jest właściwie realizowana funkcja C2 (bo np. plan miejscowy określa prawidłowo przeznaczenie terenu i zasady jego zagospodarowania), to nie mogłoby to się odbywać bez jednoczesnej właściwej realizacji innych funkcji (A, B i C1). Powyższa zależność staje się jaśniejsza, gdy uwzględnimy wcześniej poczynione uwagi na temat niesprawności władz publicznych i uwzględnimy perspektywę polityki przestrzennej jako kompleksowego systemu.

Można zastosować konkretne sposoby weryfikacji/oceny realizacji funkcji dla poszczególnych narzędzi, aby uzyskać choćby wstępną diagnozę w tym zakresie.

I tak, w przypadku kluczowej funkcji A należy zweryfikować, w jaki sposób są uwzględnione w ramach poszczególnych narzędzi przepisy bezpośrednio powołujące się na ład przestrzenny. Przy realizacji funkcji B należy natomiast zweryfikować stopień zgodności między poszczególnymi narzędziami. Powyższe wytyczne należy odpowiednio zastosować przy sektorowych bezpośrednich narzędziach polityki przestrzennej.

\section{Funkcje narzędzi polityki przestrzennej a perspektywa innych dziedzin polityki publicznej}

Zagadnienia gospodarki przestrzennej w szerszym ujęciu wiążą się z wieloma zróżnicowanymi zagadnieniami ekonomicznymi, środowiskowymi, kulturowymi czy społeczno-gospodarczymi. Tak samo funkcje narzędzi polityki przestrzennej mogą być rozpatrywane z perspektywy wymienionych wymiarów.

Najnowsza literatura przedmiotu zawiera zarówno rozważania w zakresie wpływu narzędzi polityki przestrzennej na kwestie społeczne (Włoch-Szymla, 2018: 189-191; Getimis, 2012: 25-40), środowiskowe (Szulczewska, 2018: 176-177; Giedych, 2018: 200-207; Foley et al., 2010: 955-966), jak i kwestie ochrony dziedzictwa kulturowego (Siniecka, Bogacka, Rutkowski, Sydor, 2018: 57-65). 
Zagadnieniem otwartym jest to, czy w przedstawionym powyżej kontekście różnych wymiarów polityki przestrzennej należałoby wskazywać na zupełnie osobne funkcje, które mają pełnić jej narzędzia, czy ich zastosowanie ma się odnosić do tych podstawowych celów tej polityki (raczej należy się opowiedzieć za drugim wariantem). Nie zmienia to jednak faktu, że realizacja określonych w tabeli 1 funkcji z odmiennej perspektywy może zostać sklasyfikowana inaczej.

W takim ujęciu, bezpośrednie narzędzia polityki przestrzennej odgrywają znaczącą rolę m.in. w następujących obszarach:

- ochrona środowiska i przyrody - w tym przypadku wygenerowanie rozwiązań jest uzależnione od właściwego zastosowania narzędzi polityki przestrzennej, przeznaczonych do realnej ochrony walorów środowiskowych, a w konsekwencji od kierunku polityki przestrzennej przyjętego w danej gminie w tym zakresie. Problemem w tym kontekście jest nakładanie się na siebie zróżnicowanych narzędzi ochronnych. Na przykład często występuje rozbieżność terminologiczna i instytucjonalna pomiędzy planami zadań ochronnych a miejscowymi planami zagospodarowania przestrzennego. Otwartym zagadnieniem jest też to, aby w narzędziach polityki przestrzennej w szerszym niż dotąd zakresie ujmować ważne, przekładające się na sferę realizacyjną koncepcje, np. tę związaną z „zieloną infrastrukturą",

- ochrona dziedzictwa kulturowego (zabytki, jak również krajobrazy) - obecnie zauważa się, że władze gmin w tym zakresie prowadzą dość ograniczoną aktywność planistyczną (tj. ograniczoną ochronę). Objęcie zabytków planami miejscowymi stanowiłoby znaczący element ich ochrony. Wyzwaniem jest określenie szczegółowej, optymalnej ochrony planistycznej (zarówno zgodnie z prawem w obecnie obowiązujących narzędziach polityki przestrzennej, jak też z zaplanowaniem optymalnych z tej perspektywy zmian),

- polityka społeczna - ten obszar dotyczy odpowiedniej rewitalizacji wybranych terenów. Narzędzia polityki przestrzennej powinny szerzej niż obecnie określać podstawy dla wyodrębniania istotnych z tej perspektywy stref w miastach/gminach,

- korygowanie niesprawności rynku nieruchomości (w tym likwidacja tzw. bańki spekulacyjnej na rynku nieruchomości) - należy traktować to jako zadanie, chociaż w przeważającym zakresie narzędzia polityki przestrzennej są $\mathrm{w}$ tym ujęciu wręcz przeciwskuteczne),

- tworzenie podstaw do wyceny nieruchomości - niezależnie od innych funkcji narzędzia polityki przestrzennej muszą stanowić punkt odniesienia przy dokonywanej wycenie nieruchomości, przy czym w tym ujęciu ich wzajemna pozycja znacząco się różni od ugruntowanej w ramach systemu gospodarki przestrzennej. Niewątpliwie katalog tego rodzaju obszarów jak wymienione, jest znacznie szerszy. 
Problemem jest realne uwzględnienie przy okazji prac nad poszczególnymi narzędziami polityki przestrzennej również tych, wymienionych powyżej, szczegółowych perspektyw. Zazwyczaj są one bowiem obecnie zbyt często traktowane nader ogólnie (jako proceduralna bariera utrudniająca prace nad konkretnym narzędziem), a podmioty polityki przestrzennej nie wyrażają ambicji szerszego rozwiązania wskazanych problemów przy użyciu narzędzi polityki przestrzennej. Podmioty zainteresowane sprawami środowiskowymi, kulturowymi itp. bardzo często przedstawiają koncepcje szerszego wykorzystania poszczególnych narzędzi, które ostatecznie nie są wykorzystywane. Kwestie te powinny zostać uwzględnione przy okazji dyskusji nad systemem gospodarki przestrzennej i jego możliwymi zmianami.

$* * *$

Weryfikacja sposobu realizacji funkcji właściwych dla narzędzi polityki przestrzennej w poszczególnych gminach stanowi bardzo istotne pole badawcze. Analizy z tego zakresu powinny brać pod uwagę niesprawność władz publicznych. Utrudnia to stawianie jednoznacznej diagnozy bez uwzględnienia zróżnicowanych uwarunkowań prawnych, społecznych, ekonomicznych i urbanistycznych.

Nie zmienia to jednak faktu, że funkcje narzędzi polityki przestrzennej powinny być rozumiane w szerszym zakresie problemowym, a same narzędzia - ukierunkowane na ochronę ładu przestrzennego - powinny być w szerszym niż obecnie zakresie wykorzystywane także w innych sferach: społecznych, środowiskowych, kulturowych, jak też związanych z rynkiem nieruchomości. Z perspektywy podejmowania działań związanych np. z ochroną środowiska czy dziedzictwa kulturowego poszczególne narzędzia polityki przestrzennej mogą stwarzać lepsze warunki dla tej ochrony. Aby tego rodzaju warunki występowały jednak w szerszym zakresie niż obecnie, kluczowe jest zdefiniowanie (przy pracach nad poszczególnymi narzędziami) nie tylko uwarunkowań planistycznych, ale realnych problemów związanych z wymienionymi płaszczyznami i możliwie najszersze ich uwzględnienie.

\section{Bibliografia}

Foley M.M., Halpern, B.S., Micheli, F., Armsby, M.H., Caldwell, M.R., Crain, C.M., Praler, E., Rohr, N., Sivas, D., Beck, M.W., Carr, M.H., Crowder, L.B., Duffy, J.E., Hacker, S.D., McLeod, K.L., Palumbi, S.R., Peterson, C.H., Regam, H.M., Ruckelshaus, M.H., Sandifer, P.A., Steneck, R.S. Guiding (2010). Ecological principles for marine spatial planning. Marine Policy, 34: 955-966.

Getimis, P. (2012). Comparing spatial planning systems and planning cultures in Europe. The need fora multi-scalar approach. Planning Practice and Research, 27(1): 25-40. 
Giedych, R. (2018). Ochrona przyrody w polityce przestrzennej miast. Studia KPZK PAN, t. CXC: 200-207.

Gorzym-Wilkowski, W. (2013). Planowanie przestrzenne województwa. Lublin: Wydawnictwo Uniwersytetu Marii Curie-Skłodowskiej.

Hausner, J. (2007). Polityka a polityka publiczna. Zarządzanie Publiczne, 1. Warszawa/ Kraków: Scholar: 54.

Herspergera, A., Oliveiraa, E., Pagliarina, S., Palkaa, G., Verburgb, P., Bolligera, J., Grădinarua, S. (2018). Urban land-use change: The role of strategic spatial planning. Global Environmental Change, 51: 32-41.

Izdebski, H. (2013). Ideologia i zagospodarowanie przestrzeni. Warszawa: LEX Wolters Kluwer Business.

Knieling, J., Othengrafen, F. (2015). Planning culture - A concept to explain the evolution of planning policies and processes in Europe?. European Planning Studies, 23(11): 2133-2147.

Kotulski, M. (2012). Problemy w kształtowaniu przestrzeni w procesie planowania i zagospodarowania przestrzennego, w: Przestrzeń i nieruchomość jako przedmiot prawa administracyjnego, I. Niżnik-Dobosz. Warszawa: Lexis Nexis: 39.

Kowalewski, A., Markowski, T., Śleszyński, P. (2018). Koszty chaosu przestrzennego. Studia KPZK PAN, t. CLXXXII: 7.

Kuciński, K. (2009). Geografia ekonomiczna. Kraków: Oficyna Wolters Kluwer Business.

Kwaśniak, P. (2008). Plan miejscowy w systemie zagospodarowania przestrzennego. Warszawa: Lexis Nexis.

Leoński, Z., Szewczyk, M., Kruś, M. (2012). Prawo zagospodarowania przestrzeni. Warszawa: Wolters Kluwer Business.

Małysa-Sulińska, K. (2008). Normy kształtujące ład przestrzenny. Warszawa: Wolters Kluwer Business.

Niewiadomski, Z. (2016). Planowanie i zagospodarowanie przestrzenne. Komentarz. Warszawa: Beck.

Nowak, M. (2012). Bezpośrednie instrumenty zarządzania przestrzenią jako problem badawczy. Zarządzanie Publiczne, 3. Kraków: Scholar: 53.

Nowak, M. (2017). Niesprawność władz publicznych a system gospodarki przestrzennej. Studia KPZK PAN, t. CLXXV: 221.

Siniecka, A., Bogacka, E., Rutkowski, A., Sydor, S. (2018). Wybrana problematyka z zakresu zabytków nieruchomych w dokumentach planistycznych, w: Dobre praktyki $w$ rozwoju miast $i$ wsi w zakresie przestrzennym, społecznym i środowiskowym, S. Staszewska (red.), Biuletyn KPZK PAN, 270: 57-65.

Szarfenberg, R. (2016). Polityka publiczna - nurty i zagadnienia teoretyczne. Studia z Polityki Publicznej, 1: 66.

Szulczewska, B. (2018). Zielona infrastruktura. Studia KPZK PAN, t. CLXXXIX: 176-177.

Śleszyński, P. (2013). Wskaźniki zagospodarowania i ładu przestrzennego w gminach. Biuletyn KPZK PAN, 252: 183-224. 
Włoch-Szymla, A. (2018). Instrumenty planistyczne a jakość środowiska zamieszkania w przestrzeni miasta, w: Gospodarowanie przestrzeniq miast i regionów - współczesne teorie i wyzwania praktyki, B. Luchter, P. Serafin (red). Biuletyn KPZK PAN, 272: 189-191.

Zachariasz, I. (2015). Funkcje planu miejscowego, w: Aktualne problemy zarządzania rozwojem przestrzennym w Polsce, J. Martyniuk-Pęczek, M. Nowak (red.). Biuletyn KPZK PAN: 29.

Zybała, A. (2015). Polityka publiczna wobec teorii i jej praktyki w Polsce. Wrocławskie Studia Politologiczne, 18: 33. 